\title{
Is the world getting naughtier?
}

CONSIDER the following statements:

Military expenditure by Persian Gulf states has risen fivefold in real terms between 1971 and 1975 .

In the past 25 years more than 13,000 tanks have been delivered to Middle Eastern countries.

By the year 1980 the world will be producing 80,000 kilograms of plutonium annually (8 kilograms is enough to make one nuclear weapon).

The People's Republic of China now seems to be launching satellites for military reconnaissance purposes.

About 125,000 scientists and engineers in the United States work on military research and development.

They are just a few of the pieces of information that make up the as-ever impressive compilation of military statistics put out by the Stockholm International Peace Research Institute (SIPRI) in its annual yearbook World Armaments and Disarmament (MIT Press and Almqvist \& Wiksell; SKr 106). For nearly 10 years now the world has been in SIPRI's debt for providing an endless stream of hard and almost-hard facts on military matters all around the world. It is, of course, difficult to judge what impact this impartial reporting has had on public opinion and political thinking (particularly difficult in the United Kingdom where government is distinctly exclusive and as a consequence public opinion is poorly developed on all defence matters). But the global impact has not been negligible and we must hope that the Swedish government never loses its resolve to continue to support SIPRI.

That said, it must be noted that the character of SIPRI, at least as seen through its yearbook, continues to change (as we have reported on a couple of occasions previously). More and more are personal opinions being expressed in the commentaries. Words like "bonanza", "enormity", "seemingly endless", "frightening prospect" and so on crop up increasingly often. The world as seen by SIPRI seems to be getting continually more naughty and fractious. Of course, there are good grounds for showing concern, particularly at the way in which the Third World is picking up military momentum. But there are three reasons why we believe that SIPRI should steer clear of expressing views.

First, if it can't be detached and neutral, no-one else can. There are plenty of committed institutions around the world-committed to the environment, world government, disarmament and so on. SIPRI's strength has always been its detachment; others might use its figures in any way they choose but it would simply report. Although there is much populist appeal in the path it now seems to be treading, one suspects there is less respect from the hard-headed in the armament and disarmament community.

Second, although there is really no suggestion at all that SIPRI's figures are influenced by its views, there is a risk that the sort of things it will pay attention to could be so affected. Various forms of environmental warfare are discussed in the yearbook, for instance. For example, it is suggested that the ionosphere-Earth wave guide could be used to generate very low frequency electromagnetic fields to couple into people's alpha rhythms. "If methods could be devised to produce greater field strengths . . . either by natural (for example, lightning) or artificial means, then it may become hypothetically possible to impair the performance of a large group of people in selected regions over extended periods." Now this is the idlest of coffeetable musing with, at first sight, the severest of physical objections to be laid against it. Is it right that SIPRI, in its yearbook, should be mixing such vague ideas with its strong brew of hard facts?

Third, the news is not always as bad as SIPRI makes out. "The arms race between the two great powers continued unabated", says SIPRI. But in real terms, military expenditure in the Soviet Union has held roughly constant since 1968 and in the United States has declined in the same period by more than a quarter (aided, of course, by the withdrawal from Vietnam). The world total of annual military expenditures (which includes burgeoning Middle East figures) has remained on a plateau of 210,000 million US dollars (at 1970 prices) for seven years now, and as a percentage of gross domestic product has accordingly declined steadily. It goes without saying that this is a frightening sum of money, but with growing complexity and thus cost of armaments, constant expenditure means less commitment. SIPRI's own figures seem open to more optimistic interpretations. 